\title{
HUBUNGAN ANTARA PELAYANAN KB IMPLAN DENGAN TINGKAT KEPUASAN AKSEPTOR KB IMPLAN DI WILAYAH KERJA PUSKESMAS MANDIRANCAN KABUPATEN KUNINGAN
}

\author{
${ }^{1}$ Nova Winda Setiati, ${ }^{2}$ Ai Nurasiah, ${ }^{3}$ Indri Yuliani \\ Sekolah Tinggi Ilmu Kesehatan Kuningan \\ novawindasetiati@gmail.com
}

\begin{abstract}
Abstrak
Pelayanan KB IUD adalah bagaimana akseptor dilayani oleh suatu sistem yang memberikan pelayanan KB IUD yang akan menjamin bahwa klien dilayani dengan tanggung jawab dan perhatian. Tujuan dari penelitian ini untuk mengidentifikasi pelayanan KB, mengidentifikasi tingkat kepuasan dan menganalisis adakah hubungan antara pelayanan $\mathrm{KB}$ dengan tingkat kepuasan akseptor KB implan di Wilayah Kerja Puskesmas Mandirancan. Penelitian ini bertujuan untuk menganalisis hubungan antara pelayanan KB implan dengan tingkat kepuasan pada akseptor KB implan di Wilayah Kerja Puskesmas Mandirancan Kabupaten Kuningan. Jenis penelitian ini menggunakan penelitian analitik dengan rancangan cross sectional. Populasi penelitian ini yaitu seluruh akseptor di Wilayah Kerja Puskesmas Mandirancan dengan jumlah akseptor KB implan 128 yang diambil secara total sampling instrumen penelitian ini menggunakan kuesioner. Analisis data menggunakan analisis univariat dan bivariat diuji secara chi square. Hasil penelitian didapatkan dari 82 responden dengan pelayanan yang baik sebagian besar tingkat kepuasan dalam pelayanan KB implan yaitu memuaskan (69,5\%). Berdasarkan hasil uji statistik diperoleh nilai p yaitu 0,000 dengan tingkat kemaknaan 0,05 maka dapat disimpulkan bahwa nilai p yaitu $0,000<0,05$, sehingga Ho ditolak artinya ada hubungan yang signifikan antara pelayanan KB implan terhadap kepuasan akseptor KB implan di Wilayah Kerja Puskesmas Mandirancan Kabupaten Kuningan.
\end{abstract}

Kata Kunci : Pelayanan, KB Implan, Tingkat Kepuasan, Akseptor

\section{Pendahuluan}

Keluarga Berencana adalah upaya mengatur kelahiran anak, jarak dan usia ideal melahirkan, mengatur kehamilan, melalui promosi, perlindungan, dan bantuan sesuai dengan hak reproduksi untuk 
JOURNAL OF MIDWIFERY CARE :

VOL. 01 NO. 02, JUNI 2021

DOI : $10.34305 / \mathrm{JMC} . \mathrm{V} 1 \mathrm{I} 02.255$
Ciptaan disebarluaskan di bawah

Lisensi Creative Commons Atribusi-

NonKomersial-BerbagiSerupa 4.0

Internasional.

mewujudkan keluarga yang berkualitas (Undang-Undang Republik Indonesia, 2009).

Menurut Badan Kependudukan dan Keluarga Berencana Nasional ( BKKBN ) jumlah penduduk Indonesia berpotensi menjadi yang terbesar sedunia setelah China dan India, jika laju pertumbuhannya tak bisa ditekan secara signifikan. Jumlah dan pertumbuhan penduduk Indonesia berdasarkan data sensus penduduk tahun 2010 melebihi angka proyeksi nasional yaitu sebesar 237,6 juta jiwa dengan laju pertumbuhan penduduk 1,49 per tahun. Pertumbuhan penduduk yang pesat merupakan akibat dari fertilitas yang tinggi akan menjadi sumber kemiskinan dan menghambat pertumbuhan ekonomi (BKKBN, 2011).

Salah satu masalah terpenting yang dihadapi oleh Negara berkembang, seperti di Indonesia yaitu ledakan penduduk. Dampak pertumbuhan penduduk yang cepat akan menimbulkan banyak permasalahan dalam berbagai bidang, terutama dibidang sosial dan ekonomi. Pertumbuhan penduduk yang tidak terkendali pada akhirnya akan menimbulkan kesulitan dalam pemerataan kemakmuran dan masyarakat. Menurut Arum dan Sujiyatini, untuk mengontrol laju pertumbuhan penduduk yaitu dengan gerakan keluarga berencana nasional yang bertujuan untuk meningkatkan kualitas sumber daya manusia.

Tujuan utama program KB nasional adalah untuk memenuhi permintaan masyarakat akan pelayanan KB dan kesehatan reproduksi yang berkualitas, menurunkan Angka Kematian Ibu (AKI) dan Angka Kematian Bayi (AKB), serta penanggulangan masalah kesehatan reproduksi dalam rangka membangun keluarga kecil berkualitas (Arum \& Sujiayatini, 2011).

Pelayanan KB IUD adalah bagaimana akseptor dilayani oleh suatu sistem yang memberikan pelayanan $\mathrm{KB}$ IUD yang akan menjamin bahwa klien dilayani dengan tanggung jawab dan perhatian, mendapat informasi yang memadai tentang berbagai pilihan kontrasepsi yang tersedia untuk memenuhi kebutuhan serta diberi bantuan dalam pemasangan, pelepasan dan pemilihan jenis kontrasepsi yang akan berlanjut, tanpa efek samping yang berarti hingga tujuan klien untuk menjarangkan atau membatasi kelahiran tercapai (Saifudin \& Abdul, 2005). Akses terhadap pelayanan keluarga berencana yang bermutu merupakan faktor utama penting dalam upaya mencapai 
JOURNAL OF MIDWIFERY CARE :

VOL. 01 NO. 02, JUNI 2021

DOI : $10.34305 / J M C . V 1102.255$
Ciptaan disebarluaskan di bawah

$\underline{\text { Lisensi Creative Commons Atribusi- }}$

NonKomersial-BerbagiSerupa 4.0

Internasional. pelayanan reproduksi. Puskesmas Mandirancan menempati urutan ke-4 terendah dari seluruh Puskesmas yang ada di Kabupaten Kuningan dengan pengguna KB implan sebanyak 137 akseptor (Dinas Kesehatan, 2018).

Berdasarkan data yang digali dari profil kesehatan Indonesia 2017, tercatat PUS sebanyak 37.338.265 akseptor dan jumlah akseptor KB aktif sejumlah 23.606.218 orang $(63,22 \%)$ dengan perincian penggunaan implan sebanyak 1.650.227 akseptor (6,99\%), suntik 14.817.663 akseptor (62,77\%), pil 4.069.844 akseptor (17,24\%), IUD 1.688.685 akseptor (7,15\%), MOW 655.762 akseptor (2,78\%), kondom 288.388 akseptor $(1,22 \%)$ dan MOP 124.262 akseptor $(0,53 \%)$.

Pengguna KB di Indonesia menurut profil kesehatan Indonesia tahun 2017 di dominasi oleh pengguna suntik $(62,77 \%)$, dan pil $(17,24 \%)$, sisanya menggunakan IUD $(7,15 \%)$, implan (6,99\%), MOW $(2,78 \%)$ MOP (0,53\%). Sama halnya dengan Provinsi Jawa Barat jumlah PUS 7.448.689 akseptor dimana pengguna KB di dominasi oleh jenis suntik $(63,93 \%)$ dan pil $(18,71 \%)$. Sisanya yaitu IUD $(8,85 \%)$, implan $(4,43 \%)$, MOW (2,48\%), kondom $(0,84 \%)$ dan MOP $(0,40 \%)$.
Selanjutnya penggunaan KB di Kabupaten Kuningan dengan jenis suntik $(67,2 \%)$, pil $(5,1 \%)$, kondom $(0,6 \%)$, IUD $(15,3 \%)$, implan $(7,0 \%)$ dan MOP $(0,2 \%)$ (Primadi, 2014 : 34). Sedangkan di Puskesmas Mandirancan di dapat dengan jenis suntik $(57,6 \%)$, pil $(3,4 \%)$, implan $(6,8 \%)$, IUD $(5,1 \%)$, kondom $(1,1 \%)$.

Penggunaan alat kontrasepsi implan aktif di Kabupaten Kuningan berjumlah 15,981 akseptor. Sedangkan untuk wilayah kerja Puskesmas Mandirancan sendiri pengguna KB implan aktif berjumlah 137 akseptor, dan menempati urutan ke 4 terendah dari seluruh Puskesmas yang ada di Kabupaten Kuningan. Berdasarkan data tersebut jumlah akseptor $\mathrm{KB}$ implan di Wilayah kerja Puskesmas Mandirancan masih rendah.

Berdasarkan data diatas serta hasil observasi selama kegiatan praktek lapangan di Puskesmas Mandirancan diketahui dari beberapa akseptor yang saya wawancarai lebih banyak memilih untuk menggunakan KB suntik dibanding implan dengan alasan takut dengan proses pemasangan, harga yang lumayan mahal, serta alasan ingin mempunyai anak lagi sehingga tidak mendapat dukungan dari suami. Selain itu juga ditemukan kasus pernah terjadi kegagalan pemasangan alat $\mathrm{KB}$ implan 
JOURNAL OF MIDWIFERY CARE :

VOL. 01 NO. 02, JUNI 2021

DOI : $10.34305 / J M C . V 1102.255$
Ciptaan disebarluaskan di bawah

$\underline{\text { Lisensi Creative Commons Atribusi- }}$

NonKomersial-BerbagiSerupa 4.0

Internasional.

yang mengakibatkan tangan akseptor mengalami pegal-pegal dan sulit untuk digerakan, sehingga memberikan efek trauma kepada akseptor untuk menggunakan KB implan. Setelah dilakukan pemeriksaan ternyata kapsul yang dipasang terlalu dalam sehingga mengakibatkan kapsul patah. Maka dari itu peneliti tertarik untuk melakukan penelitian guna mengetahui tingkat kepuasan akseptor dalam pelaksanaan pelayanan $\mathrm{KB}$, yang berjudul "Hubungan Pelayanan KB Implan dengan Tingkat Kepuasan Akseptor KB Implan di Wilayah Kerja Puskesmas Mandirancan”.

Berdasarkan uraian latar belakang tersebut, maka rumusan masalah dalam penelitian ini yaitu "Adakah Hubungan Antara Pelayanan KB Implan dengan Tingkat Kepuasan Pada Akseptor KB Implan di Wilayah Kerja Puskesmas Mandirancan?"

\section{Metode}

Jenis penelitian yang digunakan dalam penelitian ini adalah jenis penelitian analitik. Penelitian ini menggunakan rencana penelitian cross sectional. Populasi dalam penelitian ini adalah semua akseptor aktif KB implan yang berjumlah 128 akseptor yang berada di wilayah kerja
Puskesmas Mandirancan. Dalam penelitian ini teknik pengambilan sampel digunakan ialah teknik total sampling.

Sampel dalam penelitian ini adalah seluruh akseptor KB implan berjumlah 128 akseptor di Kecamatan Mandirancan. Variabel bebas dalam penelitian ini yaitu Pelayanan KB implan. Variabel terikat dalam penelitian ini adalah Tingkat Kepuasan Akseptor KB Implan. Analisis data dilakukan melalui dua tahapan yaitu analisis data univariat dan analisis data bivariat. Analisis bivariat juga ditunjukan untuk menguji hubungan antara variabel bebas (kualitas pelayanan KB implan) dengan variabel terikat (tingkat kepuasan akseptor KB implan). Uji statistik yang digunakan adalah dengan uji kuadrat chi square.

\section{Hasil}

Kepuasan akseptor dapat diketahui setelah akseptor menggunakan jasa pelayanan KB. Terpenuhi atau tidaknya kebutuhan dan tuntutan akseptor terkait dengan timbul atau tidaknya rasa puas terhadap pelayanan. Untuk memperkuat dugaan tersebut maka dilakukan serangkaian penelitian yang hasilnya perlu di analisis untuk membuktikan apakah ada hubungan antara pelayanan $\mathrm{Kb}$ implan 
JOURNAL OF MIDWIFERY CARE :

VOL. 01 NO. 02, JUNI 2021

DOI : $10.34305 /$ JMC.V1I02.255
Ciptaan disebarluaskan di bawah Lisensi Creative Commons Atribusi-

NonKomersial-BerbagiSerupa 4.0 Internasional.

a. Analisis Univariat

Gambaran Pelayanan Akseptor KB Implan di Wilayah Kerja Puskesmas Mandirancan Kabupaten Kuningan.

Selanjutnya dapat diketahui hasil pengolahan data menggunakan softwere statistikal product and service (SPSS).

Tabel 1. Distribusi Frekuensi Pelayanan KB Implan di Wilayah Kerja Puskesmas Mandirancan Kabupaten Kuningan

\begin{tabular}{ccc}
\hline Pelayanan & Frekuensi (F) & Presentase (\%) \\
\hline Kurang Baik & 7 & 5.5 \\
Cukup Baik & 39 & 30,5 \\
Baik & 82 & 64,1 \\
\hline Total & $\mathbf{1 2 8}$ & $\mathbf{1 0 0}$ \\
\hline
\end{tabular}

Sumber : Hasil Penelitian

Berdasarkan tabel 1 diketahui bahwa Gambaran Tingkat Kepuasan Ibu Akseptor sebagian besar responden lebih KB Implan di Wilayah Kerja Puskesmas mendapatkan pelayanan Baik yaitu 82 Mandirancan Kabupaten Kuningan.

responden $(64,1 \%)$.

Tabel 2. Tingkat Kepuasan Ibu Akseptor KB Implan Dalam Pelayanan KB Implan di Wilayah Kerja Puskesmas Mandirancan Kabupaten Kuningan

\begin{tabular}{ccc}
\hline Kepuasan & Frekuensi (F) & Persentase (\%) \\
\hline Kurang Puas & 4 & 3.1 \\
Cukup Puas & 55 & 43.0 \\
Puas & 69 & 53.9 \\
\hline Total & $\mathbf{1 2 8}$ & $\mathbf{1 0 0}$ \\
\hline
\end{tabular}

Sumber : Hasil Penelitian.

Berdasarkan tabel 2 diketahui Mandirancan yaitu sebanyak 69 responden bahwa sebagian besar responden mendapat $(53.9 \%)$,

pelayanan yang puas dalam pelayanan $\mathrm{KB}$

b. Analisis Bivariat

implan di Wilayah Kerja Puskesmas 
Tabel 3. Hubungan Antara Pelayanan Dengan Tingkat Kepuasan Akseptor KB Implan di Wilayah Kerja Puskesmas Mandirancan Kabupaten Kuningan

\begin{tabular}{|c|c|c|c|c|c|c|c|c|c|}
\hline \multirow{3}{*}{ Pelayanan } & \multicolumn{6}{|c|}{ Tingkat Kepuasan } & & & \multirow{3}{*}{ Nilai p } \\
\hline & \multicolumn{2}{|c|}{$\begin{array}{c}\text { Kurang } \\
\text { Memuaskan }\end{array}$} & \multicolumn{2}{|c|}{$\begin{array}{c}\text { Cukup } \\
\text { Memuaskan }\end{array}$} & \multicolumn{2}{|c|}{ Memuaskan } & \multicolumn{2}{|c|}{ Total } & \\
\hline & $\mathbf{n}$ & $\%$ & $\mathbf{n}$ & $\%$ & $\mathbf{n}$ & $\%$ & $\mathbf{N}$ & $\%$ & \\
\hline Kurang Baik & 4 & 57.1 & 3 & 42.9 & 0 & 0.0 & 7 & 100 & \multirow{3}{*}{0.000} \\
\hline Cukup Baik & 0 & 0.0 & 27 & 69.2 & 12 & 30.8 & 39 & 100 & \\
\hline Baik & 0 & 0.0 & 25 & 30.5 & 57 & 69.5 & 82 & 100 & \\
\hline
\end{tabular}

Sumber : Hasil Penelitian

Berdasarkan tabel 3 menunjukkan bahwa dari 82 responden yang mendapat pelayanan yang baik sebagian besar memiliki tingkat kepuasan dengan kategori memuaskan (69.5\%), dari 39 responden yang mendapat pelayanan yang cukup baik sebagian besar memiliki tingkat kepuasan dalam kategori cukup puas (69.2\%).

Berdasarkan hasil uji hipotesis menggunakan uji statistik korelasi chi square diperoleh nilai $\mathrm{p}$ yaitu 0,000 dengan tingkat kemaknaan $=0,05$ maka dapat disimpulkan bahwa nilai p sebesar 0,000 < 0,05, sehingga H0 ditolak artinya ada hubungan yang signifikan antara pelayanan KB implan terhadap tingkat kepuasan akseptor KB implan di Wilayah Kerja Puskesmas Mandirancan Kabupaten Kuningan.

\section{Pembahasan}

1. Analisis Univariat

Gambaran Pelayanan KB Implan di Wilayah Kerja Puskesmas Mandirancan Kabupaten Kuningan

Berdasarkan Tabel 1 dapat diketahui bahwa dari 128 responden, sebagian besar mendapatkan pelayanan $\mathrm{KB}$ implan yang baik yaitu 82 responden (64.1\%), sedangkan yang mendapatkan pelayanan yang cukup 39 responden (30.5\%) dan sebagian kecil responden mendapatkan pelayanan yang kurang baik yaitu 8 responden $(5.5 \%)$.

Hal ini sesuai dengan penelitian yang dilakukan oleh Wiwi Wulandari dengan hasil ada hubungan bermakna kualitas pelayanan KB dengan level kepuasan akseptor KB implant di Puskesmas Pudak Payung Kota Semarang triwulan I tahun 2015 dengan $p$ value 
JOURNAL OF MIDWIFERY CARE :

VOL. 01 NO. 02, JUNI 2021

DOI : $10.34305 / J M C . V 1102.255$

$(0,001), \mathrm{p}(0,456)$ dan nilai $95 \%$ CI $(0,255-$

0,645). Diperkuat dengan penelitian (Novia, 2017) hasilnya tingkat kepuasan $(36,8 \%)$ puas dengan nilai $\mathrm{p}>\alpha(0,650>$ 0,364) (Ndari et al., 2016).

Berdasarkan hasil penelitian tersebut sesuai dengan teori Fhirastika (2016) yang menyatakan ada lima dimensi untuk menilai mutu pelayanan kesehatan yaitu, tangibles (penampilan fisik), reability (kehandalan), responsiveness (ketanggapan), emphaty (kemampuan faham), assurance (jaminan), Hal ini dilihat dari ruang pemeriksaan yang bersih, tenang dan nyaman, petugas pelayanan berpakaian rapih dan sopan, serta obat-obatan yang tersedia cukup lengkap, dimana dalam penelitian ini kehandalan juga di nilai dari cara bidan memberikan pelayanan terhadap akseptor KB implan hasil yang didapat sebagian akseptor mengatakan bidan mampu memberikan pelayanan yang baik kepada akseptor, seperti akseptor langsung dilayani di ruang pemeriksaan $\mathrm{KB}$ dengan tanggap dan bidan memberikan pilihan $\mathrm{KB}$ apa yang akan dipakai sehingga bidan memberikan inform choise kepada akseptor tentang KB apa yang tepat untuk akseptor, tanggap dalam keluhan yang dialami oleh akseptor, bidan memberikan saran dan nasihat kepada akseptor, menjelaskan proses pelayanan, menjaga privasi akseptor dengan menutup sampiran ketika sedang pelaksanaan pemasangan implan, memberikan surat inform consent dengan KB pilihannya, bidan juga berempati dengan mendengarkan keluhan pasien dan merasakan apa yang dirasakan oleh pasien, bidan bersikap ramah dan sopan saat berkomunikasi dan memberikan tanggapan yang baik, bidan juga menjelaskan indikasi, kontraindikasi, keuntungan, kerugian, dan efek samping dari penggunaan KB implan tersebut, dengan ruangan yang nyaman, bersih, bidan mencuci tangan dan memakai sarung tangan sebelum melakukan tindakan obat dan alat kontrasepsi masih dalam keadaan bersegel. Sehingga akseptor merasa senang atas pelayanan yang didapatkan, namun ada juga beberapa akseptor yang mengatakan bidan kurang memberikan pelayanan dalam komunikasi terhadap akseptor sehingga akseptor bingung memilih KB yang tepat untuk dirinya, serta akseptor tidak mengerti apakah obat masih tersegel atau tidak karena bidan tidak memberitahu kepada akseptor KB tersebut.

Selama penelitian, peneliti juga melihat bahwa bidan di Wilayah Kerja Puskesmas Mandirancan memberikan pelayanan yang cukup baik, peneliti juga 
JOURNAL OF MIDWIFERY CARE :

VOL. 01 NO. 02, JUNI 2021

DOI : $10.34305 / J M C . V 1102.255$ melihat langsung bahwa sebagian bidan terampil dalam memberikan pelayanan kepada akseptor dan menjawab semua pertanyaan yang dikeluhkan oleh akseptor, bidan juga menjelaskan bagaimana prosedur pemasangan KB implan, menjelaskan keuntungan, kerugian dan efek samping pada pengguna KB implan, bidan juga ramah dalam berkomunikasi sehingga menimbulkan rasa aman dan nyaman pada akseptor, peneliti juga melihat ruangan yang dipakai sangat nyaman, obat dan alat yang digunakan dalam keadaan bersih dan masih bersegel, dalam melakukan tindakan bidan selalu mencuci tangan dan selalu menggunakan sarung tangan. Tetapi ada juga beberapa bidan yang kurang dalam pemberian pelayanan salah satunya yaitu kurang memberikan konseling sebelum pemberian KB implan.

Gambaran Tingkat Kepuasan Akseptor KB Implan di Wilayah Kerja Puskesmas Mandirancan Kabupaten Kuningan

Berdasarkan tabel 2 dapat diketahui bahwa dari 128 responden sebagian besar mendapatkan tingkat kepuasan yang memuaskan yaitu 69 responden $(53,9 \%)$, sedangkan yang mendapatkan kepuasan yang cukup 55 responden $(43,0 \%)$ dan sebagian kecil responden yang merasa tidak puas sebanyak 4 responden $(3,1 \%)$.
Dalam penelitian ini rata-rata responden mengatakan puas terhadap pelayanan yang diberikan seperti bidan ramah dalam melakukan komunikasi, penjelasan bidan mudah dimengerti, cepat dalam pelayanan yang diberikan, bidan memberikan penuh rasa kekeluargaan, dan dengan harga yang masih terjangkau sehingga akseptor merasa nyaman dengan pelayanan tersebut, tetapi sebagian merasa kurang puas seperti harus lebih ramah dan sopan saat berkomunikasi serta mendengarkan keluhan dengan baik, penjelasan yang disampaikan seharusnya sesuai dengan kebutuhan dan mudah dimengerti, bidan harus menjelaskan berbagai metode kontrasepsi yang ingin dipakai dan mengganti metode kontrasepsi, serta menjelaskan efek samping dan cara pemakaian. Hal ini sesuai dengan hasil survei yang dilakukan (Imbalo, 2010) terhadap 4000 pasien pada lima Puskesmas di Provinsi Jawa Tengah, di hasilkan bahwa pasien yang menyatakan pendapatnya tentang berbagai hal yang berhubungan dengan kepuasan pasien, ternyata $95 \%$ dari mereka menyatakan"Merasa Puas" dan hanya 5\% yang menyatakan "Hampir Puas" terhadap pelayanan kesehatan yang diperoleh sewaktu berobat ke Puskesmas. 
JOURNAL OF MIDWIFERY CARE :

VOL. 01 NO. 02, JUNI 2021

DOI : $10.34305 / J M C . V 1102.255$
Menurut (Imbalo, 2010), mengatakan pengukuran kepuasan pelanggan merupakan elemen penting dalam menyediakan pelayanan yang lebih baik, efisien dan efektif. Tingkat kepuasan terhadap pelayanan merupakan faktor penting yang mengembangkan suatu sistem penyediaan pelayanan yang tanggap terhadap keluhan pelanggan, meminimalkan biaya dan waktu serta memaksimalkan dampak pelayanan terhadap pasien. Tingkat kepuasan yang akurat sangat dibutuhkan dalam upaya peningkatan mutu layanan kesehatan. Dari penjelasan tersebut dapat disimpulkan bahwa kepuasan pasien adalah hasil (outcome) yang dirasakan atas penggunaan jasa pelayanan, sesuai atau melebihi harapan yang diinginkan.

2. Analisis Bivariat

Hubungan antara pelayanan dengan tingkat kepuasan akseptor KB implan di Wilayah Kerja Puskesmas Mandirancan Kabupaten Kuningan

Berdasarkan tabel 3 hasil uji statistik dengan menggunakan uji chi square dengan menggunakan program SPSS diperoleh nilai $\rho$ yaitu 0,000 dengan tingkat kemaknaan $\alpha=0,05$, maka dapat disimpulkan bahwa nilai $\rho$ sebesar $0,000<$ 0,05, sehingga Ho ditolak artinya ada hubungan antara pelayanan dengan tingkat kepuasan akseptor KB implan di Wilayah Kerja Puskesmas Mandirancan Kabupaten Kuningan. Hal ini membuktikan pelayanan $\mathrm{KB}$ implan berpengaruh signifikan terhadap tingkat kepuasan akseptor KB implan yang berarti semakin baik pelayanan yang diterima responden maka tingkat kepuasan akseptor semakin puas.

Menurut (Imbalo, 2010) bahwa hubungan antara pelayanan KB implan terhadap tingkat kepuasan akseptor $\mathrm{KB}$ implan. Hal ini menunjukan semakin baik pelayanan yang diberikan pada responden maka semakin tinggi juga tingkat kepuasan responden dan semakin kurang pelayanan yang diberikan pada responden maka tingkat kepuasan responden semakin tidak puas. Adanya hubungan ini juga berguna untuk meningkatkan pelayanan kesehatan untuk dapat memahami dan melaksanakan pelayanan yang sesuai standar guna meningkatkan kepuasan pasien.

Didukung dengan penelitian sebelumnya Nia Wahyuningrum dengan judul "Gambaran Tingkat Kepuasan Pasien Terhadap Kualitas Pelayanan KB AKBK (Alat Kontrasepsi Bawah Kulit)" di Puskesmas Wonosobo I Kecamatan Wonosobo Kabupaten Wonosobo, telah melakukan penelitian sebanyak 85 
JOURNAL OF MIDWIFERY CARE :

VOL. 01 NO. 02, JUNI 2021

DOI : 10.34305/JMC.V1I02.255 responden dengan hasil analisis menunjukan bahwa pasien merasa sangat puas terhadap kualitas pelayanan $\mathrm{KB}$ AKBK di Puskesmas Wonosobo I dengan prosentase sebesar 77,70\% (Wahyuningrum \& Sutomo, 2013).

Berdasarkan hasil penelitian dan teori yang dikemukakan oleh para ahli tersebut maka penulis berasumsi bahwa, pelayanan yang baik bagi klien biasanya dikaitkan dengan terpenuhinya kebutuhan pelayanan, kecepatan pelayanan, keramahtamahan dan tarif yang murah. Sebaiknya akseptor akan menganggap pelayanan jelek apabila menurut akseptor tersebut pelayanan tidak sesuai keinginan, antri lama, petugas pelayanan tidak ramah meskipun petugas tersebut profesional. Dan ada beberapa akseptor juga yang masih merasa pelayanan yang diberikan kurang baik biasanya faktor tersebut dari status pendidikan akseptor yang lebih tinggi dari bidan tenaga pelayanan KB tersebut. Meski terkadang kelalaian yang dilakukan pelayan $\mathrm{KB}$ tidak terlalu fatal namun bisa saja sangat mempengaruhi kepuasan akseptor contohnya, bidan pelayanan KB yang harus selalu bersikap ramah dan sopan terhadap setiap akseptor. Jadi pelayanan menurut akseptor atau klien berkaitan dengan kepuasan. Dalam melaksanakan peningkatan pelayanan dan kinerja perlu adanya prinsip yaitu antara lain dimulai dengan data, komitmen dan konsisten serta berkesinambungan, konseling yang baik, bekerja sesuai standar dan berfokus pada kepuasan akseptor atau klien.

\section{Kesimpulan}

Berdasarkan hasil penelitian tentang hubungan pelayanan dengan tingkat kepuasan klien dalam pelayanan KB implan di Wilayah Kerja Puskesmas Mandirancan Kabupaten Kuningan maka penulis membuat kesimpulan sebagai berikut :

1. Sebagian besar akseptor mendapatkan pelayanan KB implan dengan kategori baik sebanyak $69,5 \%$

2. Sebagian besar akseptor implan memiliki tingkat kepuasan dengan kategori puas sebanyak $69,5 \%$

3. Terdapat hubungan antara pelayanan dengan tingkat kepuasan akseptor KB implan di Wilayah Kerja Puskesmas Mandirancan Kabupaten Kuningan dengan nilai $\rho=0,000$

\section{Saran}

Disarankan kepada akseptor untuk lebih bisa menyampaikan pendapat mengenai pelayanan yang ada dan bidan atau pusat kesehatan masyarakat yang ada 
JOURNAL OF MIDWIFERY CARE :

VOL. 01 NO. 02, JUNI 2021

DOI : $10.34305 / J M C . V 1102.255$

di Mandirancan untuk bisa mempertahankan kualitas pelayanan yang baik serta meningkatkan sosialisasi mengenai $\mathrm{KB}$ implan agar akseptor $\mathrm{KB}$ implan lebih meningkat.

\section{Daftar Pustaka}

Arum, D. N. S., \& Sujiayatini. (2011). Panduan Lengkap Pelayanan KB Terkini. Nuha Medika.

BKKBN. (2011). Pedoman Pelayanan KB Dalam Jaminan Kesehatan Masyarakat.

Dinas Kesehatan. (2018). Rencana Strategis Dinas Kesehatan Kabupaten Kuningan. Departemen Kesehatan Republik Indonesia. kuningankab.go.id

Imbalo, S. P. (2010). Jaminan Mutu. Kesaint Blanc.

Ndari, W. W., Dharminto, D., \& Nugroho, D. (2016). Hubungan Tingkat Kemandirian dan Kualitas Pelayanan $\mathrm{Kb}$ dengan Level Kepuasan Akseptor $\mathrm{Kb}$ Implan di Puskesmas Pudak Payung Kota Semarang Triwulan I Tahun 2016. Jurnal Kesehatan Masyarakat (e-Journal), 4(3), 26-35.

Novia. (2017). Hubungan Pelayanan KB IUD Terhadap Tingkat Kepuasan Akseptor KB IUD. Profesi, 14(2).

Saifudin, \& Abdul, B. (2005). Buku Panduan Praktis Pelayanan Kesehatan Maternal \& Neonatal. Yayasan Bina Pustaka Sarwaono Prawirohardjo.
Undang-Undang Republik Indonesia. (2009). Nomor 52 Tahun 2009 Tentang perkembangan Kependudukan dan Pembangunan Keluarga.

Wahyuningrum, N., \& Sutomo, A. H. (2013). Gambaran Tingkat Kepuasan Pasien terhadap Kualitas Pelayanan KB AKDR (Alat Kontrasepsi dalam Rahim) di Puskesmas Wonosobo I Kecamatan Wonosobo Kabupaten Wonosobo. [Yogyakarta]: Universitas Gadjah Mada. 